\title{
Marine Diatoms Grown in Chemostats under Silicate or Ammonium Limitation. II. Transient Response of Skeletonema costatum to a Single Addition of the Limiting Nutrient*
}

\author{
H. L. Conway, P. J. Harrison ${ }^{\star *}$ and C. O. Davis ${ }^{* * *}$ \\ Department of Oceanography, University of Washingotn; Seattle, Washington, USA
}

\begin{abstract}
Skeletonema costatum was grown at different steady-state growth rates in ammonium or silicate-limited chemostats. The culture was perturbed from its steady-state condition by a single addition of the limiting nutrient, ammonium or silicate. The transient response was followed by measuring nutrient disappearance of the limiting and non-limiting nutrients at frequent time intervals. The results from a typical perturbation experiment indicate that three distinct modes of uptake of the limiting nutrient can be distinguished; surge uptake $\left(V_{s}\right)$, internally controlled uptake $\left(V_{j}\right)$, and externally controlled uptake $\left(V_{e}\right)$. An interpretation of these three modes of uptake is given and their relation to control of uptake of the limiting nutrient is discussed. The uptake rates of the non-limiting nutrients were shown to be depressed during the surge of the uptake of the limiting nutrient. Kinetic uptake parameters, $K_{S}$ and $V_{\max }$, were obtained from data acquired during the externally controlled uptake segment, $V_{e}$. The same $V_{\max }$ value of $0.12 \mathrm{~h}^{-1}$, was obtained under either silicate or ammonium limitation. Estimates of $K_{S}$ were $0.4 \mu \mathrm{g}-$ at $\mathrm{NH}_{4}-\mathrm{N} 1^{-1}$ and $0.7 \mu \mathrm{g}-\mathrm{at} \mathrm{Si} 1^{-1}$. Short-term $15_{\mathrm{N}}$ uptake-rate measurements conducted on nitrogen-limited cultures appear to be a combination of $V_{S}$ or $V_{i}$, or at lower substrate concentrations $V_{s}$ and $V_{e}$. It is difficult to separate these different uptake modes in batch or tracer experiments, and ensuing problems in interpretation are discussed.
\end{abstract}

\section{Introduction}

The uptake of the limiting nutrient by phytoplankton has been described by a rectangular hyperbola, similar to the Michaelis-Menten equation for enzyme kinetics; $V=V_{\max } \cdot S / K_{S}+s$, where $V$ is the velocity of uptake, $V_{\max }$ the maximal velocity, $s$ the concentration of nutrient, and $K_{S}$ the half-saturation con-

* Contribution No. 882 Erom the Department of Oceanography, University of Washington, Seattle, Washington 98195, USA. This work represents a portion of three dissertations submitted to the Department of Oceanography, University of Washington, Seattle, in partial fulfillment of the requirements for the Ph.D. degree.

** Present address: Institute of Oceanography, University of British Columbia, Vancouver V6T 1W5, British Columbia, Canada.

*** Present address: Great Lakes Research Division, University of Michigan, Ann Arbor, Michigan 48105, USA. stant, the value of $s$ when $V=V_{\max } / 2$. In the past, the uptake rates of nitrogen and silicate have been obtained primarily from batch experiments (Eppley and Thomas, 1969; Eppley et al., 1969; Paasche, 1973). In a typical experiment, different amounts of the limiting nutrient were added to a series of culture flasks. Uptake rates were calculated from the difference in the limiting nutrient concentration at the beginning and end of the experimental period. Nitrogen uptake rates, using the stable isotope, $15 \mathrm{~N}$, were measured in a similar way (MacIsaac and Dugdale, 1972). The measurement of the uptake rate in this type of experiment, in which only a single end-point measurement is made, gives only an average uptake rate over the experimental time period.

Recently, Caperon and Meyer (1972) introduced an important refinement in the determination of uptake rate through the use of the perturbation experiment. They used chemostats to prepare popula- 
tions representing a variety of known conditioning states. At steady state, the culture was perturbed by a spike addition of the limiting nutrient and the rate of decline in its concentration was followed by repeated sequential sampling. Their sampling intervals varied between 4 and $14 \mathrm{~min}$. The use of chemostats to precondition the algal population was also used by Eppley and Renger (1974) in their study of nitrate and ammonium uptake kinetics.

These workers (Caperon and Meyer, 1972; Eppley and Renger, 1974) have shown that the uptake kinetics reflect the preconditioning nutrient experience of the population. However, there is still no general agreement on just how the uptake rate is related to the particulate nitrogen/cell or cell quota, $Q$. For example, Eppley and Renger (1974) found that $V_{\max }$ per unit cell nitrogen was inversely proportional to dilution rate. This agrees with amino acid uptake studies conducted by North and Stephens (1971). However, Caperon and Meyer (1972) observed a direct correlation between $V_{\max }$ and the pre-existing dilution rate. clearly, this relationship between the uptake rate of the limiting nutrient and the pre-existing dilution rate (preconditioning nutrient experience) needs further investigation for nitrogen limitation, and especially for silicate limitation, since no data exist on this relationship.

In the experiments described in this paper, the perturbation technique was used to document the time-series response of the uptake rate of the limiting nutrient and non-limiting nutrients to a single addition of the limiting nutrient, silicate or ammonium. Additional short-term $15 \mathrm{~N}$ batch experiments on steady-state ammonium-limited cultures were conducted, to determine uptake characteristics for a range of ammonium concentrations, before the degree of nitrogen deficiency was changed drastically by the utilization of large amounts of ammonium.

\section{Materials and Methods}

Description of Chemostat system

The chemostat system and the source of the inoculum of skeletonema costatum used in this study have been described previously (Davis et al., 1973). Concentrations of the major nutrients in the ammonium-limited artificial seawater were

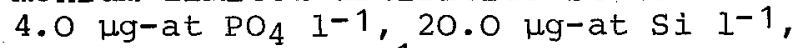
$0.5 \mu \mathrm{g}$-at $\mathrm{NO}_{3}-\mathrm{N} 1^{-1}$, and $10.0 \mu \mathrm{g}-\mathrm{at}$
$\mathrm{NH}_{4}-\mathrm{N}$ 1-1; concentrations of trace metals and vitamins were approximately $f / 50$ (Guillard and Ryther, 1962).

Cells were grown in ammonium-limited chemostats under continuous light and in silicate-limited chemostats under continuous light or under a $16 \mathrm{~h}$ light: $8 \mathrm{~h}$ dark photoperiod. The light intensity

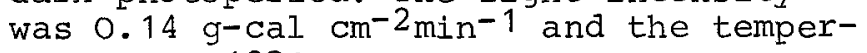
ature was $18^{\circ} \mathrm{C}$.

\section{Analyses and Sampling}

Methods for nutrient analyses and cell measurements have been described elsewhere (Davis et al., 1973). Particulate nitrogen (PN) and particulate silica (PSi) were calculated from inorganic nutrient analyses of inflow minus outflow. Statistical variation of these methods of analyses and $15_{\mathrm{N}}$ uptake rates are given elsewhere (Conway, 1974; Harrison, 1974).

Daily effluent samples were taken and measurements of fluorescence, cell counts, and concentrations of nitrate, ammonium, phosphate and silicate were made. When no trend in these parameters was observed for several days, it was assumed that steady state had been attained and a perturbation experiment was initiated to evaluate the nutrient-uptake response of the population to additions of the limiting nutrient.

\section{Perturbation Experiment}

In the perturbation experiment the concentration of the limiting nutrient in the reactor was increased from the steady-state value, usually $<0.5 \mu \mathrm{g}$-at $1^{-1}$ to a high value, $>7 \mu g-a t 1^{-1}$, by the spike addition of a known amount of the limiting nutrient. The concentrations of the limiting nutrient and nonlimiting nutrients were measured as often as every $6 \mathrm{~min}$, to follow their disappearance from the medium.

Two types of perturbation experiments were used. In the continuous-mode experiment, pumping of the inflow medium into the reactor vessel was continued after addition of the limiting nutrient. In the second type, a batch-mode experiment, pumping of inflow medium was stopped after addition of the limiting nutrient. The latter type of experiment had the advantage of being shorter.

During the perturbation experiment, sampling of a chemostat was carried out through the use of a PDP-11/20 computer (Digital Equipment Corporation), which executed a sequence of programs called 
the Laboratory Operating System (LOS) (Shields and Pollack, 1972). A schematic diagram of the automated sampling system is shown in Fig. 1. The sampling procedure began with two rinses of the sample lines and the sample receptacle. Next, a 40-ml sample from a chemostat was transferred rapidly across to the sample receptacle, where it was pumped first through a fluorometer and then to an AutoAnalyzer ${ }^{\circledR}$. The remaining sample was released through a dump valve, and the receptacle was washed with deionized water for $1 \mathrm{~min}$ in preparation for the next sample. Under this sampling scheme, a chemostat sample could be taken every $6 \mathrm{~min}$.

Calculations of Uptake Rate from Nutrient Disappearance

\section{Continuous-Mode Perturbation Experiments}

The equations describing the chemostat during transient state were used to calculate the uptake rate during continuousmode perturbation experiments. The following equations were adapted from Herbert et a1. (1956).

$$
\frac{d S}{d t}=D S i-D S-\frac{v X}{Y},
$$

where $x=$ concentration of organisms in particulate form ( $\left.\mu g-a t l^{-1}\right), t=$ time, $V=$ specific uptake rate $h^{-1}, D=$ dilution rate, i.e., flow rate/volume of chemostat $h^{-1}, s=$ limiting substrate concentration in the reactor vessel ( $\mu g-$ at $\left.1^{-1}\right), s_{i}=$ inflowing limiting substrate concentration ( $\mu \mathrm{g}-\mathrm{at} \mathrm{1}^{-1}$ ), and $Y=$ yield "constant" $1=\frac{d X}{d S}$. After solving for $V$ we have:

$$
V=\left(D(S i-S)-\frac{d S}{d t}\right) / X \text {. }
$$

In finite difference form:

$$
V=\left(D(S i-\bar{S})-\frac{\Delta S}{\Delta t}\right) / \bar{x},
$$

where $\bar{S}$ and $\bar{X}$ are average values during the time interval $\Delta t$.

The changes in particulate nitrogen (PN) or particulate silica (PSi) can be described by the equation

$$
\begin{aligned}
& \frac{d X}{d t}=V X-D X, \\
& \frac{d X}{X}=(V-D) d t,
\end{aligned}
$$

\footnotetext{
${ }^{1}$ In short-term studies involving the measurement of the uptake rate of the limiting substrate, $Y=1$ if excretion is assumed to be negligible.
}

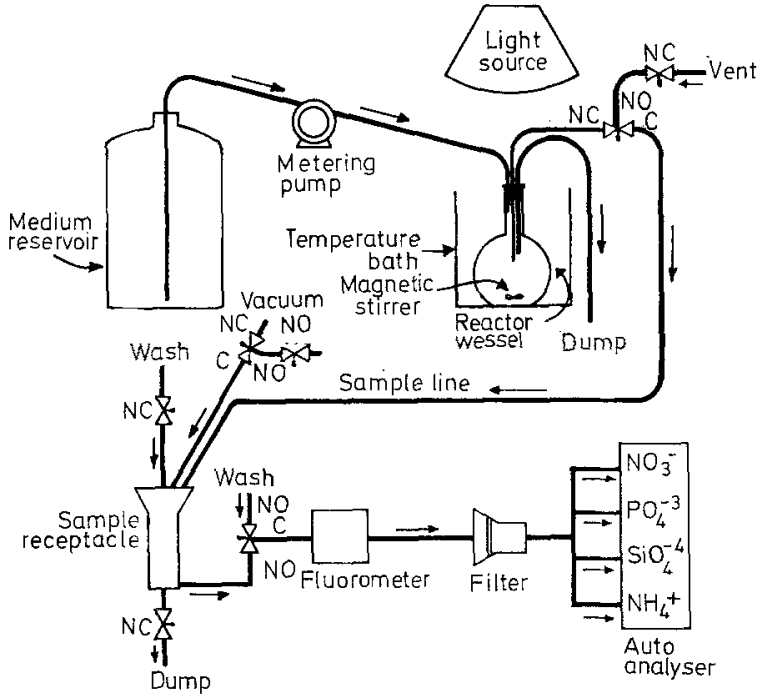

Fig. 1. Schematic diagram of chemostat and automated sampling system. NC: Normally closed; NO: normally open; $\mathrm{C}$ : Common

where $x=$ PN or PSi (ug-at $\left.1^{-1}\right)$. Upon integration:

$$
\ln \frac{x}{x_{O}}=(V-D) t
$$

Taking the exponents of both sides:

$$
x=x_{0} e^{(V-D) t} \text {. }
$$

The PN or PSi concentration in the reactor during a perturbation experiment is described by Eq. (3) .

\section{Batch-Mode Perturbation Experiments}

During a batch-mode perturbation experiment $D=0$, and since there were no losses or additions of nitrogen or sili$\mathrm{Ca}$ from the reactor vessel, Eq. (2) takes the form:

$$
v=\frac{\Delta S}{(\Delta t)(x)} .
$$

Assuming no excretion of nitrogen or silica, the increase in PN or PSi should be equal to the disappearance of inorganic nitrogen or silicate from the medium.

\section{${ }^{15}$ Studies}

The ${ }^{15} \mathrm{~N}$ studies consisted of two experiments. Three steady-state chemostat populations grown at different dilution rates were used for each experiment. Subsamples of the steady-state populations were placed in a series of incubation bottles and appropriate amounts of $15 \mathrm{NH}_{4}$ 


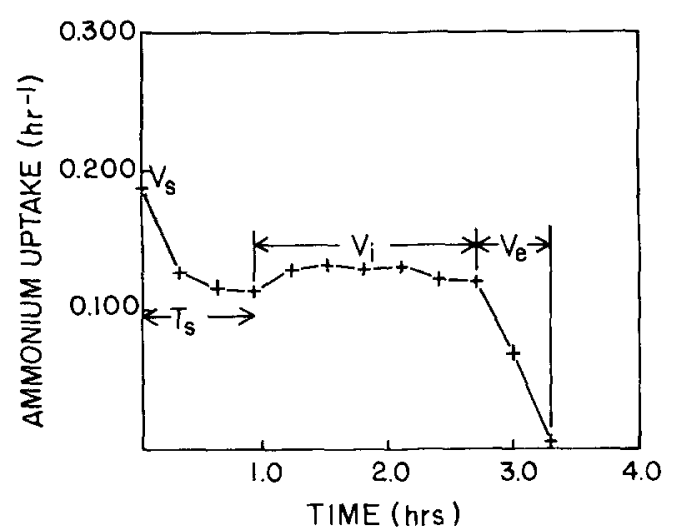

Fig. 2. Skeletonema costatum. Ammonium-uptake rate during batch-mode ammonium-limited perturbation experiment I-BMP-3 $\left(D=0.040 \mathrm{~h}^{-1}\right)$. The ammonium-uptake rate has been divided into 3 segments, $V_{S}, V_{i}, V_{e}$, which are defined in text

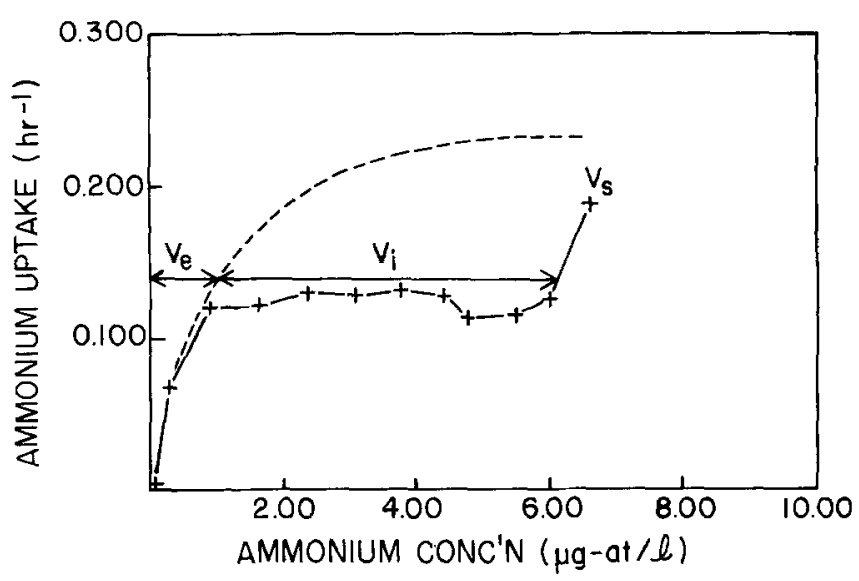

Fig. 3. Skeletonema costatum. Ammonium-uptake rate as function of ammonium concentration during batch-mode ammonium-limited perturbation experiment I-BMP-3 $\left(D=0.040 \mathrm{~h}^{-1}\right)$. The two data points in $V_{e}$ segment of uptake curve were used to produce dashed hyperbola were added. Medium $\mathrm{f} / 50$ without nitrogen was added to ensure saturation of the other essential micronutrients. Two-hour incubations were carried out under the same conditions of light and temperature that existed in the chemostat. After incubation, the cells were filtered on to glass-fiber filters and dried at $60^{\circ} \mathrm{C}$ in a vacuum desiccator before analysis. The samples were analyzed for the $15 \mathrm{~N}: 14 \mathrm{~N}$ ratio, and particulate nitrogen content according to Pavlou et al. (1974).

\section{Results}

Ammonium Limitation

\section{Perturbation Studies}

Three experiments were conducted. Experiment I consisted of batch-mode perturbation (BMP) experiments on the populations from three chemostats, connected in series to form multiple or tandem reactors. Inflow medium was pumped into the first chemostat (BMP-3); the outflow of this reactor flowed into the next (BMP-2), and its outflow entered the last reactor $(B M P-1)$. The result was a series of three populations, each more nitrogen-limited than the preceding one. Experiments II and III were continuousmode peturbation (CMP) experiments, using chemostats operated as single reactors.

The results from a BMP experiment are shown in Fig. 2. Three distinct modes of uptake of the limiting nutrient can be distinguished:

Surge Uptake, $V_{S}$. The time interval, $T_{S}$, over which the surge uptake occurs, is defined as the time from the addition of the limiting nutrient until $\Delta v / \Delta t$ first takes on a positive value, following the high initial uptake rate. The magnitude of $V_{s}$ was estimated from the highest value of uptake rate obtained during the time interval $T_{S}$.

Internally controlled uptake, $V_{i} . V_{i}$ is defined as the mean uptake rate beginning at the end of time period ${ }^{T}$ and continuing until the uptake rate decreases rapidly. $V_{i}$ can be considered as an apparent substrate-saturated uptake rate.

Externally Controlled Uptake, $V_{e} \cdot V_{e}$ begins when the uptake rate appears to be a function of decreasing substrate concentrations.

Grouping of the data into these distinct modes of uptake was necessary since it appeared that different mechanisms were responsible in each case. In Fig. 3, the break in the ammoniumuptake curve signaling the beginning of external control, can be seen at approx-

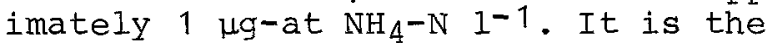
uptake rate from this externally-controlled segment that should be used to evaluate the Michaelis constants $V_{\max }$ and $K_{S}$. The number of useful data points in this experiment was reduced to two or three by this analysis. If a hyperbola was fitted to these points, as shown in Fig. 3, a higher estimate of $V_{\max }$ and $K_{S}$ was obtained than if a hyperbola was fitted to the combined results of $V_{e}$ and $v_{i}$ segments of the data, as has been done customarily in the past. For ammonium, the number of data points that can be obtained in this $V_{e}$ segment are small since the segment generally 


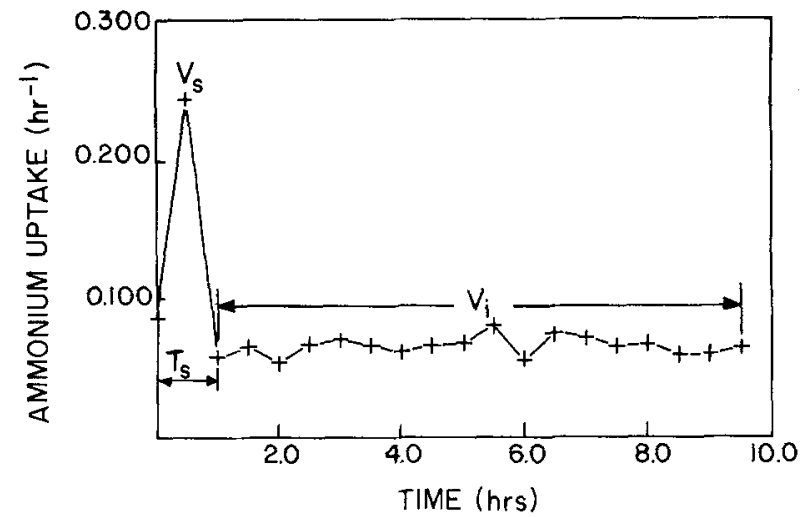

Fig. 4. Skeletonema costatum. Ammonium-uptake rate during continuous mode, $\mathrm{NH}_{4}-1$ imited perturbation experiment III-CMP-4 ( $D=0.052 \mathrm{~h}-1)$

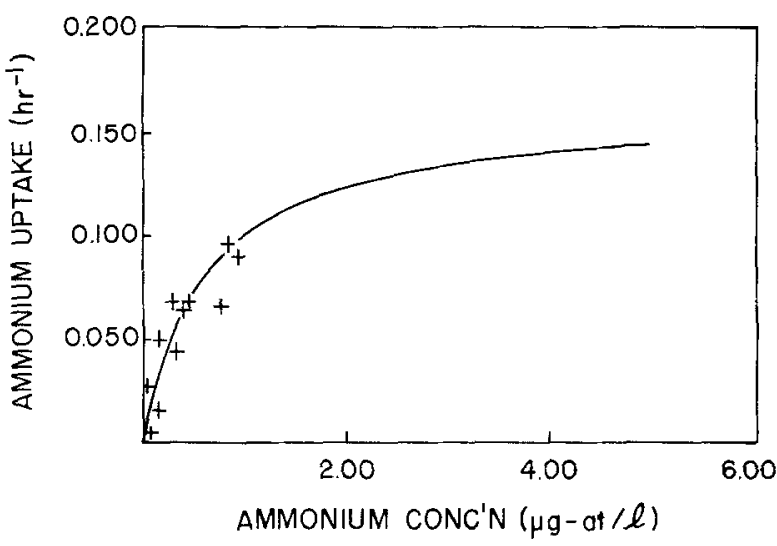

Fig. 5. Skeletonema costatum. Ammonium-uptake rate $\left(V_{e}\right)$ as function of ammonium concentration at substrate concentrations less than $1 \mu g-a t$ 1-1. Uptake values and corresponding ammonium concentrations were obtained from Experiments I and. II. Values were pooled in order to obtain estimates of $V_{\max }$ and $K_{S}$, which were $0.125 \mathrm{~h}^{-1}$ and $0.44 \mu \mathrm{g}$-at $1^{-1}$, respectively occurs at concentrations of less than $1 \mu g$-at $\mathrm{N}^{-1}$. The experimental period can be stretched by using the continuous-mode experiment; however, it may extend for too long a period, as shown in Fig. 4 where values of $v_{e}$ were not observed within the 10-h duration of the experiment.

The values of $V_{e}$ and ammonium concentration obtained in Experiments $I$ and II (from 5 perturbation experiments) were pooled, since only 2 or 3 data points from the $v_{e}$ segment were obtained in each experiment. One hyperbola was fitted to the pooled data (Cleland, 1967), giving a value of $V_{\max }=0.125 \mathrm{~h}^{-1}$ and $k_{S}=0.44 \mu \mathrm{g}$-at $1^{-1}$ (Fig. 5). However, $V_{\max }$ should be estimated for each experiment if enough data points are available. For example, the estimate of $K_{S}$ and $V_{\text {max }}$ from the pooled data (from 5 experiments) appeared to underestimate the values of the kinetic parameters for one of these experiments (BMP-3, Fig. 3).

Results of the three perturbation experiments (I, II and III) are summarized in Table 1, except for the values of $V_{e}$. Within each experiment (I, II and III), the magnitude of $V_{s}$ was generally inversely proportional to cellular nitrogen content (Q) but there was no apparent correlation with cell surface area or volume. It should be kept in mind that the estimate of $v_{s}$ was often from a single-point measurement and may not be a good estimate of its absolute magnitude. The values of $V_{i}$ in Table 1 increase with decreasing nitrogen/cell, except for BMP-1 and BMP-2; these populations were quite different from the others since they were from the second and third reactors in the tandem arrangement and probably represent cells that were approaching nitrogen starvation.

Phosphate- and silicate-uptake rates were calculated for the three batch-mode perturbation experiments in Experiment I to examine the effect that the surge in ammonium- (the limiting nutrient) uptake had on the utilization of these non-limiting nutrients; the latter were at saturating concentrations throughout the experiment. These data are summarized in Table 2, and one example of the pattern of phosphate and silicate uptake is presented in Fig. 6. These results show that during the surge of ammonium uptake, the uptake rates of phosphate and silicate were depressed, and they have been denoted as Vlag in Table 2 . The lag time in Table 2 refers to the time from initial exposure to the higher concentration of ammonium until phosphate- and silicate-uptake rates began to continuously increase; this was usually about $0.6 \mathrm{~h}$. The depression of phosphate uptake during the lag period was complete, while silicate utilization was strongly depressed but never to undetectable rates. Under ammonium limitation, the uptake rate of silicate during the depression period was directly proportional to nitrogen/cell, and the uptake rates of phosphate and silicate after the depression were also directly proportional to nitrogen/cell (Table 2). 
Table 1. Skeletonema costatum. Values of surge uptake $\left(V_{S}\right)$, internally controlled uptake $\left(V_{i}\right)$, and time interval $\left(T_{S}\right)$, from 3 sets of ammonium-limited perturbation experiments (designated I, II, and III), with corresponding values of particulate nitrogen/cell, dilution rate, cell surface area, and cell volume. Reactors in Experiment I were connected in series, with result that Populations BMP 1 and -2 may represent populations that were approaching starvation and thus are not directly comparable with the other 5 populations

\begin{tabular}{|c|c|c|c|c|c|c|c|c|}
\hline $\begin{array}{l}\text { Experiment } \\
\text { identifi- } \\
\text { cation }\end{array}$ & $\begin{array}{l}D, \\
\text { dilution } \\
\text { rate } \\
\left(\mathrm{h}^{-1}\right)\end{array}$ & $\begin{array}{l}Q, \\
\mathrm{PN} / \text { cell } \\
(\mu \mathrm{g}-\mathrm{at} \\
\left.\operatorname{cell}^{-1} \times 10^{-7}\right)\end{array}$ & $V_{s}\left(h^{-1}\right)$ & $\begin{array}{l}V_{i}^{*} \\
\left(h^{-1}\right)\end{array}$ & $\begin{array}{l}T_{S} \\
(\mathrm{~h})\end{array}$ & $\begin{array}{l}\text { Cell } \\
\text { surface } \\
\text { area } \\
\left(\mu \mathrm{m}^{2}\right)\end{array}$ & $\begin{array}{l}\text { Cell } \\
\text { volume } \\
\left(\mu \mathrm{m}^{3}\right)\end{array}$ & $\begin{array}{l}\text { Sampling } \\
\text { interval } \\
\text { (h) }\end{array}$ \\
\hline \multicolumn{9}{|l|}{ I } \\
\hline BMP- 1 & 0.040 & 0.34 & 0.218 & $\begin{array}{l}0.098 \\
(n=3)\end{array}$ & 1.8 & 213.9 & 222.0 & 0.3 \\
\hline $\mathrm{BMP}-2$ & 0.040 & 0.36 & 0.235 & $\begin{array}{l}0.103 \\
(n=8)\end{array}$ & 1.2 & 263.4 & 300.3 & 0.3 \\
\hline $\mathrm{BMP}-3$ & 0.040 & 0.47 & 0.188 & $\begin{array}{l}0.130 \\
(n=6)\end{array}$ & 0.9 & 267.0 & 291.2 & 0.3 \\
\hline \multicolumn{9}{|l|}{ II } \\
\hline CMP- 1 & 0.040 & 0.52 & 0.276 & $\begin{array}{l}0.096 \\
(n=4)\end{array}$ & 3.2 & 146.6 & 108.9 & 0.5 \\
\hline CMP-2 & 0.047 & 0.67 & 0.196 & $\begin{array}{l}0.088 \\
(n=18)\end{array}$ & 2.7 & 154.4 & 128.2 & 0.5 \\
\hline \multicolumn{9}{|l|}{ III } \\
\hline $\mathrm{CMP}-3$ & 0.049 & 0.73 & 0.284 & 0.060 & 1.0 & 246.4 & 263.8 & 0.5 \\
\hline CMP-4 & 0.052 & 0.84 & 0.245 & $\begin{array}{l}0.064 \\
(n=18)\end{array}$ & 1.0 & 234.3 & 254.3 & 0.5 \\
\hline
\end{tabular}

* Mean value of $n$ data points are shown in parentheses.

Table 2. Skeletonema costatum. Mean uptake rates of non-limiting nutrients, phosphate and silicate, during batch-mode $\mathrm{NH}_{4}$-limited perturbation experiments on tandem reactors $(D=0.04 \mathrm{~h}-1)$. Numbers of observations in parentheses

\begin{tabular}{|c|c|c|c|c|c|c|c|c|c|}
\hline $\begin{array}{l}\text { Experiment } \\
\text { identifi- } \\
\text { cation }\end{array}$ & $\begin{array}{l}\text { Time lag } \\
\left(\mathrm{PO}_{4}\right) \\
(\mathrm{h})\end{array}$ & $\begin{array}{l}\text { Phosphate } \\
V_{\text {lag }} \\
\left(h^{-1}\right)\end{array}$ & 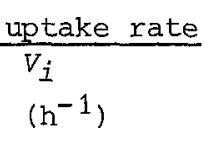 & $\begin{array}{l}\text { Time lag } \\
\left(\mathrm{SiO}_{4}\right) \\
(\mathrm{h})\end{array}$ & $\frac{\text { Silicate }}{V_{\text {lag }}}$ & 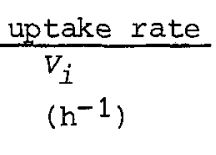 & $\begin{array}{l}Q^{*} \\
(\mu g-a t \\
c e l 1^{-1} \\
\left.x \quad 10^{-7}\right)\end{array}$ & $\begin{array}{l}V_{i}\left(\mathrm{NH}_{4}\right) * \\
\left(\mathrm{~h}^{-1}\right)\end{array}$ & $\begin{array}{l}T_{S} \text { * } \\
(\mathrm{h})\end{array}$ \\
\hline BMP-1 & 0.6 & $\begin{array}{l}\text { ud } \\
(3)\end{array}$ & $\begin{array}{l}0.059 \\
(12)\end{array}$ & 0.6 & $\begin{array}{l}0.004 \\
(3)\end{array}$ & $\begin{array}{l}0.087 \\
(15)\end{array}$ & 0.34 & 0.098 & 1.8 \\
\hline$B M P-3$ & 0.6 & $\begin{array}{l}\text { ud } \\
\text { (3) }\end{array}$ & $\begin{array}{l}0.075 \\
(12)\end{array}$ & 1.5 & $\begin{array}{l}0.020 \\
(6)\end{array}$ & $\begin{array}{l}0.110 \\
(12)\end{array}$ & 0.47 & 0.130 & 0.9 \\
\hline
\end{tabular}

ud: Undetectable.

* Data from Table 1. 


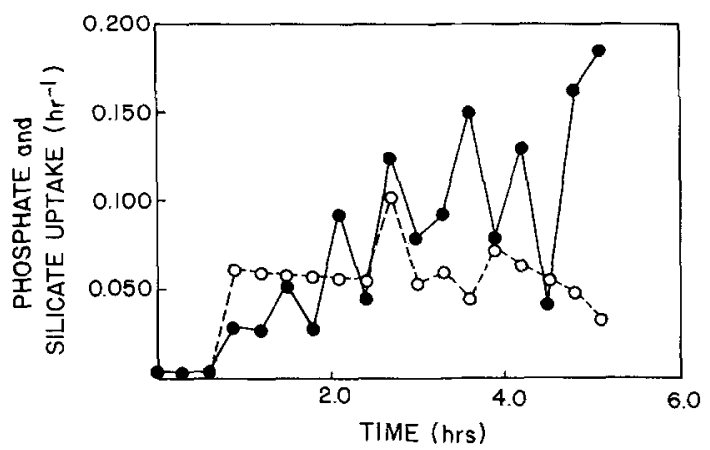

Fig. 6. Skeletonema costatum. Uptake rates of non-limiting nutrients, phosphate (open circles) and silicate (filled circles) during batch-mode, ammonium-limited perturbation experiment I-BMP-1 $\left(D=0.040 \mathrm{~h}^{-1}\right)$. About $7 \mu \mathrm{g}$-at $\mathrm{NH}_{4}-\mathrm{N} \mathrm{l}^{-1}$ were added at $t=0 \mathrm{~h}$ to an ammonium-limited steadystate population

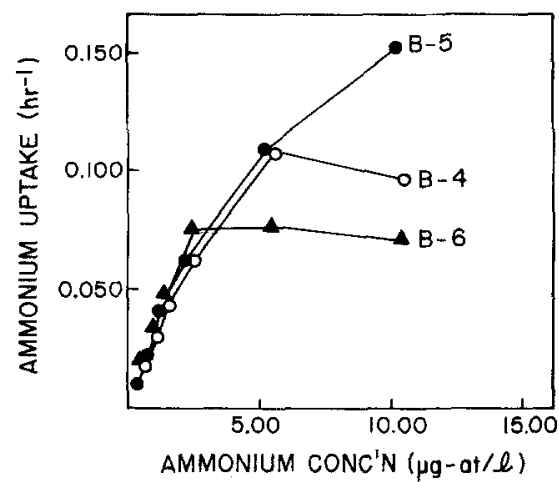

Fig. 7. Skeletonema costatum. Ammonium uptake as function of ammonium concentration during ammonium-limited batch $15 \mathrm{~N}$ experiments. Each uptake-rate measurement represents mean value over $2-\mathrm{h}$ incubation period. Dilution rates were $\mathrm{B}-5=$ $0.044 \mathrm{~h}^{-1}, \mathrm{~B}-4=0.037 \mathrm{~h}^{-1}$, and $\mathrm{B}-6=0.052 \mathrm{~h}^{-1}$; nitrogen/cell, $Q$, is given in Table $3 ; \mathrm{B}-5$ had lowest value of $Q$
Table 3. Skeletonema costatum. Relationship between $V_{i}$ and $\mathrm{N} / \mathrm{cell}$ for both series of batch $15_{\mathrm{N}}$ experiments

\begin{tabular}{lllll}
\hline $\begin{array}{l}\text { Experiment } \\
\text { identifi- } \\
\text { cation }\end{array}$ & $\begin{array}{l}\text { Precondi- } \\
\text { tioning } \\
\text { dilution } \\
\text { rate }\left(\mathrm{h}^{-1}\right)\end{array}$ & $\begin{array}{l}\text { PN/cell } \\
(\mu g-a t \\
\text { celi-1 } \\
\left.\times 10^{-7}\right)\end{array}$ & $\begin{array}{l}V_{i} * \\
\left(\mathrm{~h}^{-1}\right)\end{array}$ & $\begin{array}{l}\text { Saturating } \\
\text { ammonium } \\
\text { concentration } \\
\left(\mu g-a t 1^{-1}\right)\end{array}$ \\
\hline B-5 & 0.044 & 0.21 & $0.152^{\mathrm{a}}$ & $>10.0$ \\
B-4 & 0.037 & 0.27 & 0.096 & 5.0 \\
B-1 & 0.042 & 0.27 & $0.081^{\mathrm{a}}$ & $>10.0$ \\
B-2 & 0.048 & 0.46 & 0.070 & 5.0 \\
B-6 & 0.052 & 0.46 & 0.066 & 2.5 \\
B-3 & 0.058 & 0.78 & 0.037 & 1.5 \\
\hline
\end{tabular}

*aken as first data point exhibiting substrate saturation in $\mathrm{V}_{\mathrm{NH}}$ versus $\mathrm{NH}_{4}$ concentration plots.

a Not true value of $V_{i}$ because substrate saturation was not observed; included only for comparison.

\section{$15_{\mathrm{N}}$ studies}

Results from the $15_{\mathrm{N}}$ batch experiments (Table 3) on steady-state chemostat populations provided further insight into the nature of the changes in $V_{i}$ associated with ammonium Iimitation. The data from one such experiment are plotted in Fig. 7, where the uptake hyperbola is represented by the curve for Population B-5; this population had the lowest nitrogen/cell. Populations B-4 and $B-6$ followed the same uptake hyperbola, but showed truncation. These truncation levels were interpreted to be the result of internal cellular control and equivalent to $V_{i}$ of the perturbation experiments as previously defined.

$v_{i}$ values from both series of $15 \mathrm{~N}$ experiments showed an inverse relation- ship with corresponding values of $\mathrm{PN} / \mathrm{cell}$ (Table 3). The ammonium concentration, corresponding to the point at which saturation appears to occur, was inversely proportional to PN/cell. The value of $V_{i}$ from these $15 \mathrm{~N}$ experiments were compared to those from the perturbation studies and their relationship to particulate nitrogen/cell (Q) is presented in Fig. 8. The values of $V_{i}$ showed the same pattern as those values from perturbation experiments, although lying below the latter.

\section{Silicate Limitation}

The results of perturbation studies on silicate-limited populations exhibited a time-series pattern of uptake rate similar to that described above for ammonium-limited populations. An example of the uptake rate pattern for one perturbation experiment is shown in Fig. 9 , and the data from other perturbation experiments are summarized in Table 4. The silicate concentration where the silicate uptake rate began to decrease rapidly, due to external substrate control, usually occurred at approximately $3 \mu \mathrm{g}-$ at $\mathrm{Si} \mathrm{1}^{-1}$. The value of $V_{e}$ for three experiments in Table 4 have been pooled and assumed to be described by MichaelisMenten kinetics (Fig. 1OA). Estimates of $K_{S}$ and $V_{\max }$ were $0.7 \mu \mathrm{g}$-at $\mathrm{Si} \mathrm{I}^{-1}$ and $0.112 h^{-1}$, respectively. Recent experiments in which the sampling interval in the $v_{e}$ region was as short as 6 min have yielded better estimates of $K_{s}(1.3 \mu g-$ 


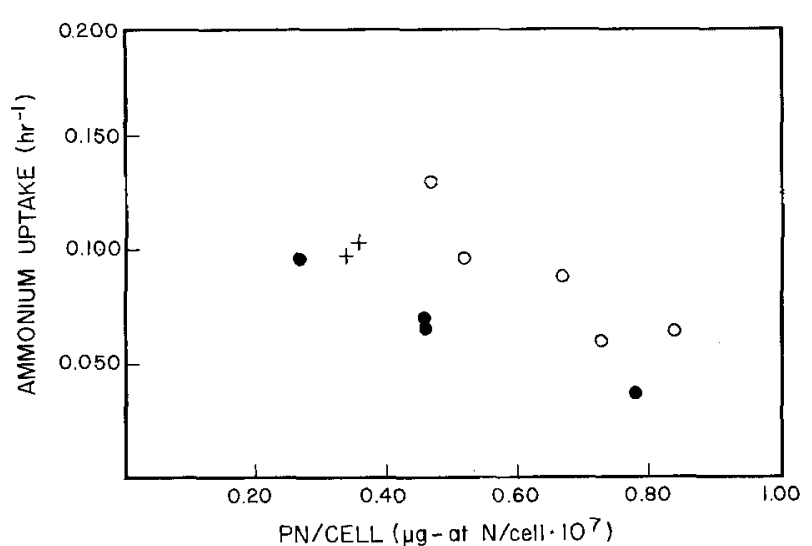

Fig. 8. Skeletonema costatum. Ammonium-uptake rate $\left(V_{i}\right)$ as function of $\mathrm{PN} / \mathrm{cell}$ from $15_{\mathrm{N}}$ (filled circles) and perturbation experiments (open circles). Uptake rates (crosses) are from second (I-BMP-2) and third (I-BMP-1) reactors of tandem arrangement from Experiment I

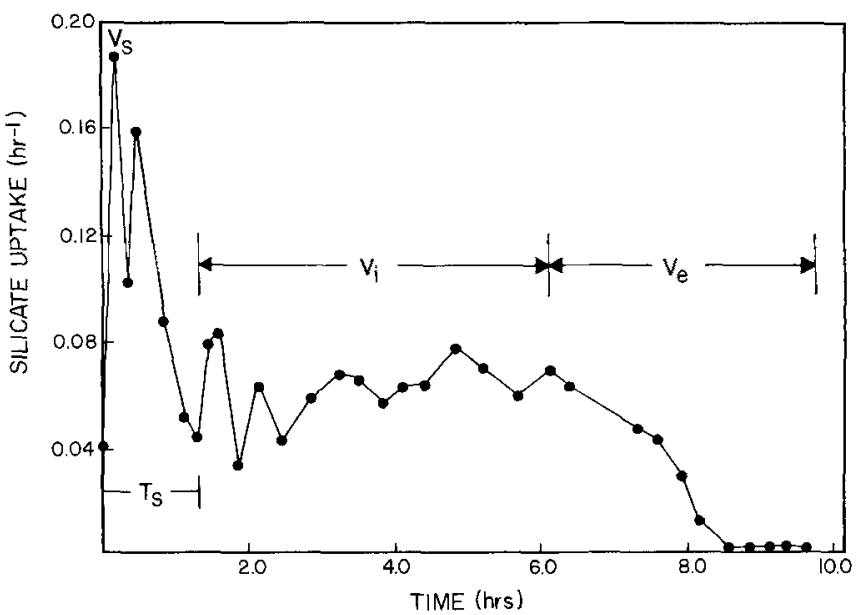

Fig. 9. Skeletonema costatum. Silicate-uptake rate after addition of about $10 \mu \mathrm{g}$-at $\mathrm{Si}^{-1}$ at $t=0 \mathrm{~h}$, during batch-mode, Si-limited perturbation experiment $\left(D=0.040 \mathrm{~h}^{-1}\right)$. Symbols are defined in text at $\left.\mathrm{Si} \mathrm{1}^{-1}\right)$ and $V_{\max }\left(0.10 \mathrm{~h}^{-1}\right)$. An example of the data from one such experiment is shown in Fig. 10B. This experiment and others will be described in more detail in a subsequent paper (Breitner and Harrison, in preparation).

The values of $V_{i}$ and silica/cell (Q) from Table 4 exhibited an approximate inverse relationship (Fig. 11). The values of $V_{S}$ in Table 4 are higher than the $V_{\max }$ values obtained from the data in Fig. 9, in agreement with the results for ammonium.

Uptake rates of the non-limiting nutrients, phosphate and nitrate were calculated for two batch-mode perturbation experiments and are summarized in Table 5. The uptake rates for phosphate and nitrate (denoted as Vlag) were depressed for the first hour, coinciding with the surge in the uptake rate of the limiting nutrient, silicate. The time lag in Table 5 refers to the time interval from addition of the limiting nutrient (silicate) until phosphate and nitrate uptake rates begin to increase. The degree of depression of the nitrate uptake rate was slight.

\section{Discussion}

Interpretation of perturbation and $15 \mathrm{~N}$ Studies

Perturbation studies

Ideas and interpretations of the perturbation studies can be presented within a theoretical framework, formulated from
Table 4. Skeletonema costatum. Values of $V_{S}, V_{i}$ and $T_{S}$ from Si-limited perturbation experiments, with corresponding values of PSi/cell, dilution rate, and cell volume. Dash: No data

\begin{tabular}{|c|c|c|c|c|c|}
\hline $\begin{array}{l}\text { Dilution } \\
\text { rate } \\
\left(h^{-1}\right)\end{array}$ & $\begin{array}{l}Q \\
\text { ( } \mu g-a t \text { si } \\
\text { cel1-1 } \\
\left.\times 10^{-7}\right)\end{array}$ & $\begin{array}{l}V_{s} \\
\left(h^{-1}\right)\end{array}$ & $\begin{array}{l}V_{i}{ }^{*} \\
\left(h^{-1}\right)\end{array}$ & $\begin{array}{l}T_{S} \\
(h)\end{array}$ & $\begin{array}{l}\text { Cell } \\
\text { volume } \\
\left(\mu \mathrm{m}^{3}\right)\end{array}$ \\
\hline 0.031 & 0.39 & 0.200 & $\begin{array}{l}0.095 \\
(8)\end{array}$ & 1.8 & 135 \\
\hline $0.033^{\mathrm{a}}$ & 0.38 & 0. 180 & $\begin{array}{l}0.060 \\
(6)\end{array}$ & 1.4 & 150 \\
\hline $0.035^{\mathrm{a}}$ & 0.32 & 0.195 & $\begin{array}{l}0.065 \\
(12)\end{array}$ & 0.9 & 130 \\
\hline 0.036 & 0.39 & 0.162 & $\begin{array}{l}0.065 \\
(11)\end{array}$ & 2.0 & 98 \\
\hline 0.036 & 0.45 & 0.195 & $\begin{array}{l}0.070 \\
(7)\end{array}$ & 0.7 & 199 \\
\hline 0.040 & 0.26 & - & $\begin{array}{l}0.074 \\
(8)\end{array}$ & - & 99 \\
\hline 0.040 & 0.33 & - & $\begin{array}{l}0.088 \\
(8)\end{array}$ & 0.6 & 99 \\
\hline 0.041 & 0.33 & 0.170 & $\begin{array}{l}0.060 \\
(15)\end{array}$ & 1.3 & - \\
\hline 0.040 & 0.28 & 0.180 & $\begin{array}{l}0.070 \\
(15)\end{array}$ & 1.3 & - \\
\hline 0.050 & 0.19 & 0.167 & $\begin{array}{l}0.133 \\
(4)\end{array}$ & 0.8 & $\sim 125$ \\
\hline 0.050 & 0.25 & 0.155 & $\begin{array}{l}0.104 \\
(8)\end{array}$ & 1.0 & $\sim 125$ \\
\hline 0.054 & 0.35 & 0.178 & $\begin{array}{l}0.110 \\
(6)\end{array}$ & 0.9 & $\sim 125$ \\
\hline
\end{tabular}

\footnotetext{
* Mean value of $\mathrm{n}$ data points are shown in parentheses.

$a_{V_{e}}$ values used in Fig. $10 \mathrm{~A}$ were derived from these experiments.
} 

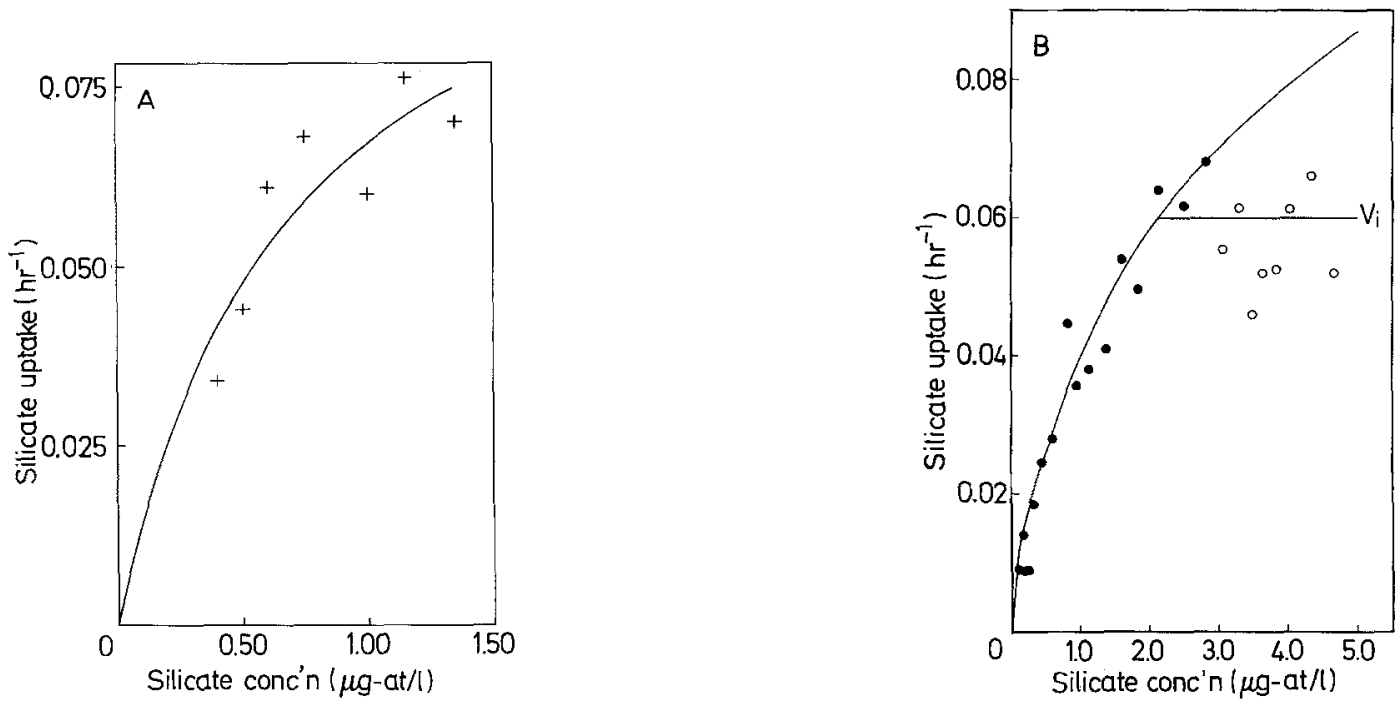

Fig. 10. Skeletonema costatum. Silicate-uptake rate $\left(V_{e}\right)$ as function of silicate concentration at substrate concentrations less than $5 \mu \mathrm{g}$-at $\mathrm{Si} \mathrm{1}^{-1}$. In $(\mathrm{A})$, the values of $V_{e}$ and silicate concentration were obtained from 3 experiments in Table 4 , and have been pooled. Estimates of $V_{\text {max }}$ and $K_{S}$ were $0.112 \mathrm{~h}^{-1}$ and $0.7 \mu g$-at $\mathrm{Si} 1-1$, respectively. In (B), values of $V_{e}$ (filled circles) and $V_{i}$ (open circles) were obtained from one experiment; estimates of $V_{\max }$ and $K_{S}$ were $0.10 \mathrm{~h}^{-1}$ and $1.3 \mu \mathrm{g}$-at $\mathrm{Si} \mathrm{l}^{-1}$, obtained from a hyperbola fitted to $V_{e}$ values only. $V_{i}$ values have been included to demonstrate truncation effect

Table 5. Skeletonema costatum. Mean uptake rates of non-limiting nutrients, phosphate and nitrate, during two batch-mode si-limited perturbation experiments. Number of observations in parentheses

\begin{tabular}{|c|c|c|c|c|c|c|c|c|}
\hline $\begin{array}{l}\text { Dilution } \\
\text { rate } \\
\left(h^{-1}\right)\end{array}$ & $\begin{array}{l}\text { Time lag } \\
\mathrm{PO}_{4} \\
(\mathrm{~h})\end{array}$ & 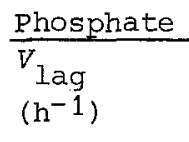 & $\frac{\text { uptake rate }}{V_{i}}$ & $\begin{array}{l}\text { Time lag } \\
\mathrm{NO}_{3} \\
(\mathrm{~h})\end{array}$ & $\frac{\text { Nitrate }}{\begin{array}{c}V_{\text {lag }} \\
\left(h^{-1}\right)\end{array}}$ & $\frac{\text { uptake rate }}{V_{i}}$ & $\begin{array}{l}V_{i} \\
\left(\mathrm{SiO}_{4}\right) \\
\left(\mathrm{h}^{-1}\right)\end{array}$ & $\begin{array}{l}T_{S} \\
(\mathrm{~h})\end{array}$ \\
\hline 0.040 & 0.6 & $\begin{array}{l}0.016 \\
(10)\end{array}$ & $\begin{array}{l}0.040 \\
(15)\end{array}$ & 0.9 & $\begin{array}{l}0.035 \\
(10)\end{array}$ & $\begin{array}{l}0.040 \\
(15)\end{array}$ & 0.070 & 1.3 \\
\hline 0.041 & 0.8 & $\begin{array}{l}0.030 \\
\text { (5) }\end{array}$ & $\begin{array}{l}0.038 \\
(15)\end{array}$ & 1.2 & $\begin{array}{l}0.035 \\
(5)\end{array}$ & $\begin{array}{l}0.040 \\
(15)\end{array}$ & 0.060 & 1.3 \\
\hline
\end{tabular}

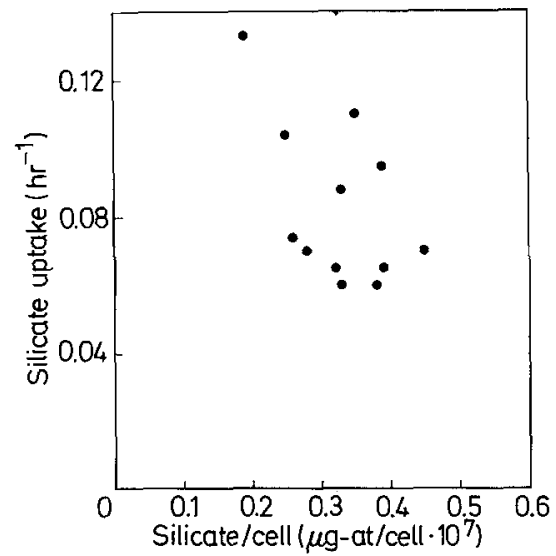

Fig. 11. Skeletonema costatum. Relationship between cell quota, Si/cell, and internally controlled uptake rate, $V_{i}$, for Si-limited perturbation experiments in Table 4 the results of these studies (Fig. 12). The observed uptake rate $\left(V_{e}\right)$ is represented as a function of external substrate concentration until this concentration increases to a level sufficient to saturate the assimilatory enzyme system. The external substrate concentration at this point is designated $s_{t}$. At substrate concentrations greater than $S_{t}$, the uptake rate $\left(V_{i}\right)$ is approximately constant until the cellular nitrogen or silica content is increased to a nondeficient level. When this occurs the uptake rate and growth rate are coupled and the cell can effectively maintain a non-deficient chemical composition. The capacity of the permease system, at increasing substrate concentration, is represented as a hyperbolic curve from which $v_{i}$ branches. The maximum capacity 


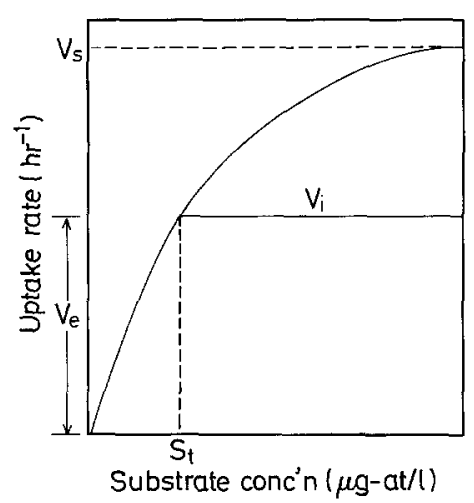

Fig. 12. Skeletonema costatum. Theoretical interpretation of $V_{S}, V_{i}$, and $V_{e}$ formulated from results of ammonium- and silicate-perturbation experiments

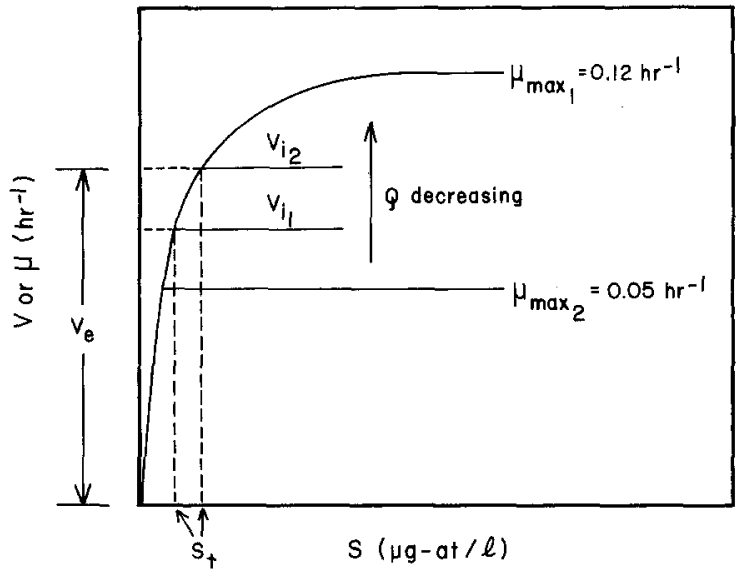

Fig. 13. Skeletonema costatum. Relationship between uptake rate measured during perturbation studies and maximal growth rate measured at steady state of the permease system would be proportional to the surge of uptake $v_{S}$. Since this surge in uptake appears to last up to $1 \mathrm{~h}$, it appears that we are not measuring the absorption phenomenon that Droop (1973) has observed.

our initial experiments indicated that the optimum procedure for obtaining estimates of the $V_{e}$ segment is to add a large enough spike of the limiting nutrient to allow the $V_{S}$ and $v_{i}$ segments to be separated from $V_{e}$. Other experiments (Harrison and Conway, in preparation) indicate that two small additions of the limiting nutrient produce estimates of the uptake kinetics similar to those produced by a single large addition; however, a third small addition resulted in a much lower estimate of $V_{\max }$. Therefore, kinetic estimates may be sensitive to the duration of exposure to the saturating nutrient concentration (limiting nutrient). The experimental design should also be such that the maximum number of data points are obtained in the $V_{e}$ segment by increasing the number of measurements taken during this segment.

The estimates of $K_{S}$ and $V_{\max }$ obtained for silicate-limited populations are more precise than for ammonium limitation because the hyperbola is truncated at a higher substrate concentration, thereby allowing more measurements of $V_{e}$ to be taken. The estimates of $V_{\max }$ and $K_{s}$ for skeletonema costatum of $0.11 h^{-1}$ and $0.7 \mu \mathrm{g}$-at $\mathrm{Si} \mathrm{1}^{-1}$, respectively, agree with literature values (Davis, 1973; Paasche, 1973).

The $V_{i}$ segment of the uptake curve (see Fig. 3) is represented as a truncation or branching from the permease uptake hyperbola (Fig. 12). The data in Tables 1 and 4 indicate that the magnitude of $V_{i}$ is approximately inversely proportional to $Q$, the cell quota; this is shown in Fig. 13 as a series of truncation levels, accompanied by a series of $S_{t}$ values. The range of $V_{i}$ 's was approximately 0.05 to $0.12 \mathrm{~h}^{-1}$, which is approximately the same as the two maximal growth rates established for steadystate populations of Skeletonema costatum under ammonium and silicate limitation (Harrison et al., 1976).

Values of $s_{t}$, obtained from perturbation experiments, were approximately $1 \mu \mathrm{g}$-at $\mathrm{NH}_{4}-\mathrm{N} 1^{-1}$ and $3 \mu \mathrm{g}-$ at $\mathrm{SiO}_{4}-\mathrm{Si}$ 1-1. The slope of the hyperbola is sufficiently steep in the region where $V_{i}$ branches that $s_{t}$ appears to be a constant value for each limitation (ammonium or silicate). In reality, analytical measurements are not sensitive enough to distinguish differences in $s_{t}$. Sampling intervals also restrict the effectiveness of separating $s_{t}$ 's. Because of the rapid change in substrate with time, an infinitely small $\Delta t$ would have to be approached before differences in $s_{t}$ could be distinguished. 
In a previous paper (Harrison et al., 1976), the growth kinetics of skeletonema costatum were described. Two and possibly three physiological states were identified, each state having a different maximal growth rate. The theoretical interpretation presented in Fig. 13 is based on populations that have a common maximal growth rate of $0.05 h^{-1}$ (i.e., from Region 2 as defined by Harrison et al., 1976). For these populations, uptake and growth in terms of cell $\mathrm{N}$ or cell $\mathrm{Si}$, are uncoupled during a perturbation experiment. The uptake rate, represented by $V_{i}$, is higher than the maximal growth rate $\left(\mu_{\max }\right)$. When the cell quota increases and approaches a maximum $(Q \longrightarrow$ $\left.Q_{\text {max }}\right)$ during a long perturbation experiment, $V_{i}$ would be expected to shift to a maximal growth rate of $0.12 \mathrm{~h}^{-1}$ as previously suggested (Harrison et al. 1976 ). During the course of a typical perturbation experiment, the coupling of $v_{i}$ and $\mu_{\max }$ has not been observed because of the short duration of the experiment ( 4 to $12 \mathrm{~h}$ ).

The elevated rate of ammonium uptake by N-depleted cells is well known, i.e., uncoupling between growth and uptake (Eppley and Thomas, 1969; Caperon and Meyer, 1972; Eppley and Renger, 1974). The above workers have measured values of $V_{\max }$ which we interpret to be equivalent to $V_{i}$ values. The observation in our study that $V_{i}$ was inversely proportioned to the degree of nitrogen deficiency of the cell or pre-existing dilution rate agrees with observations made by North and Stephens (1971) and Eppley and Renger (1974).

There is no published data on the relationship between $V_{i}$ and the preexisting dilution rate or silica deficiency. However, the increased values of $V_{i}$ at lower dilution rates may simply be due to the decreasing values of $Q$, since it is used in the normalization of the specific uptake rate $\left(h^{-1}\right)$. In a subsequent paper of this series, Dugdale (in preparation) examines the data in this paper and others, using cellular transport of the limiting nutrient as a more reliable indicator to evaluate shift-up (incremental increase) in the nutrient uptake rate.

The $V_{s}$ segment of the uptake curve was observed in all perturbation experiments on silicate-limited or ammoniumlimited skeletonema costatum populations. The $V_{S}$ segment implies a permease capacity that exceeds (initially) the internal utilization rate. Recent studies in this laboratory, on ammonium-limited $s$. costatum populations, have shown an increase in the intercellular pool of ammonium during the $V_{S}$ segment (Quay
Dortch, personal communication) lending credence to the idea of an enhanced permease capacity during the initial stages of a perturbation experiment. This type of phenomenon has also been observed in bacteria (Fisher et al., 1973; Bremer and Dennis, 1975) and marine algae (Caperon and Meyer, 1972; Droop, 1973), although in the two studies on marine algae the surge in uptake was either not mentioned or attributed to adsorption.

\section{$15_{\mathrm{N}}$ studies}

The same features observed in the perturbation studies can be seen in the results of the $15_{\mathrm{N}}$ experiments. $v_{e}$ was evident until a saturating ammonium concentration was reached, $s_{t}$. At this point the apparent substrate-saturated uptake rate $V_{i}$ was observed, with the exception of two of the more nitrogendeficient populations $(B-1$ and $B-5)$. The uptake curves of these two populations ( $B-1$ and $B-5)$ may be proportional to the capacity of the permease system at increasing substrate levels (see Fig. 12), since neither population exhibited a substrate saturation uptake rate $\left(V_{i}\right)$. All $v_{i}$ values fell within the growth rate range of 0.05 to $0.12 \mathrm{~h}^{-1}$, as observed in the perturbation studies, except for the population exhibiting the largest value of $Q(B-3)$.

The biggest difference between the results of the $15_{\mathrm{N}}$ and perturbation studies was in values of $s_{t}$. $s_{t}$ values for the $15 \mathrm{~N}$ studies ranged from 1.5 to $5 \mu \mathrm{g}$-at $\mathrm{NH}_{4} 1^{-1}$, compared to values of approximately $1 \mu g$-at $\mathrm{NH}_{4}-\mathrm{N} 1^{-1}$ from the perturbation studies. However, there was a basic difference in the two types of experiments. The duration of the $15 \mathrm{~N}$ experiments was $\leq 2 \mathrm{~h}$. In perturbation experiments, $s_{t}$ values were determined after the populations had been exposed to high levels of ammonium for approximately 2.5 to $7.5 \mathrm{~h}$. Another complication is that $15_{\mathrm{N}}$ uptake-rate measurements from N-Iimited populations are usually a combination of $V_{S}$ and $v_{i}$, or at lower substrate concentrations $V_{S}$ and $v_{e}$.

The most immediate problem for batch and tracer studies on nutrient-limited populations lies in separating $v_{s}$ from $v_{e}$ or $v_{i}$ measurements. It would appear that modifications in the experimental design should be made for some experiments. For example, pre-incubation of $\mathrm{N}$-limited cells under saturating nitrogen conditions for 1 to $2 \mathrm{~h}$, would allow a measurement of $V_{i}$ to be made after that time. 
Proposed Mechanism for Control of Uptake and Assimilation of Ammonium and Silicate

Sims et al. (1968), working with yeast, found that the level of total amino acids inside the cell appeared to regulate the maximal rate of ammonium uptake by feedback control. In the present study, the uptake and assimilation of ammonium was assumed to be influenced by the level of total amino acids in the cell through feedback control of the permease system. The uptake of ammonium and subsequent rise in the total amino acid pool could theoretically result in a decrease of the effective permease concentration. Variations in the effective permease concentration may be the result of: (1) an inhibitor affecting the site of enzyme synthesis; or (2) an inhibitor combining with the enzyme or enzyme-substrate complex, thereby preventing the enzyme from functioning. This inhibition would result from a rise in the total amino acid level during ammonium uptake. The total amino acid level would, in turn, be determined by the nutritional state of the cell. Cells grown at high dilution rates $\left(>0.060 \mathrm{~h}^{-1}\right)$ have a higher nitrogen content (Harrison et al., 1976). In these cells, the protein content is assumed high and all amino acid pools are theoretically filled. Since the cell has no large nitrogen quota to fill, a reduction in the catalytic capacity of the permease system occurs. Restraint is placed on the permease system by the high level of total amino acids found in the non-limited cell. As the dilution rate decreases, the cells shift into a nitrogen-depleted condition and the amino acids inside the cell are reduced. The subsequent reduction in the total amino acid pool would increase the effective permease concentration, thereby increasing the rate of ammonium utilization.

Evidence for increasing protein levels (and probably amino acid levels) with increasing dilution rate has recently been documented and will be described further in a mathematical model of nitrogen uptake and assimilation (Conway et al., in preparation). The proposed mechanism for the control of the uptake and assimilation of ammonium is analogous to that proposed for phosphoruslimited Scenedesmus sp. (Rhee, 1973).

A similar mechanism has been proposed for silicate utilization. For silicatelimited populations, it is assumed that there is one internal pool containing approximately $3 \%$ of the total cellular silica (Werner, 1966; Azam et al., 1974). The level of this pool controls the uptake of silicate by feedback control and, when the pool is full, the rate-limiting step becomes the incorporation of silicate from the pool into the shell. These relationships will be described further in a mathematical model of silicate uptake and growth of diatoms (Davis et al., in preparation).

\section{Conclusions}

The consequences of this view of nutrient-limited uptake and growth affect not only the interpretation of the results of chemostat-culture experiments, but also the interpretation of $29 \mathrm{Si}$ and $15 \mathrm{~N}$ tracer experiments. The values of $V_{\max }$ in the literature, obtained from shortterm batch experiments would contain the same problems of interpretation as those for $15 \mathrm{~N}$ measurements. Perturbation experiments, in which $V_{i}$ and $V_{S}$ values were not isolated from $V_{e}$ values, would not yield true estimates of $V_{\max }$ and $K_{\mathbf{S}}$. Kinetic data obtained and analyzed properly should yield values of $V_{\max }$ and $K_{S}$ which are more reliable, based on data corresponding more closely to Michaelis-Menten kinetics.

In the first paper of this series (Harrison et al., 1976), a shift-up in the maximal growth rate was documented for populations that were grown at high dilution rates. Bacteriological studies indicate that the shift-up in the growth rate is the last of a sequence of events to occur (Schaechter, 1968). In this study we have looked at the initial step in the shift-up, the response in uptake rate to an addition of the limiting nutrient, which would be somewhat analogous to a large increase in the dilution rate. The uncoupling between uptake and growth and cellular control over uptake, by increasing the uptake rate of the limiting nutrient and depressing the uptake rate of the non-limiting nutrients, are some of the important features of this early phase of shift-up. Other intermediate events, such as an increase in cellular amino acids and protein, are now under study. Knowledge of this sequence of events should prove to be important in understanding the mechanisms by which the cell controls uptake and growth and in understanding the outcome of species competition experiments.

Acknowledgements. This research was supported by National Science Foundation Grants GB 6394 , GA 31093 and GB 20182. D. Harmon assisted in maintenance of the chemostats and data analysis. G. Friederich maintained the AutoAnalyzer. Discussions and critical reading of manuscript by Drs. R.C. Dugdale, M. Mickelson and T.E. Whitledge were extremely helpful. 


\section{Literature Cited}

Azam, F., B.B. Hemmingsen and B.E. Volcani: Role of silicon in diatom metabolism. Arch. Mikrobiol. 97, 103-114 (1974)

Bremer, H. and P.P. Dennis: Transition period following a nutxitional shift-up in the bacterium Escherichia coli B/r: stable RNA and protein synthesis. J. theor. Biol. 52, 365382 (1975)

Caperon, J. and J. Meyer: Nitrogen-limited growth of marine phytoplankton. Part II. Uptake kinetics and their role in nutrient Iimited growth of phytoplankton. Deep-Sea Res. 19, 619-632 (1972)

Cleland, $w .:$ The statistical analysis of enzyme kinetic data. Adv. Enzymol. 29, 1-32 (1967)

Conway, H.I.: The uptake and assimilation of inorganic nitrogen by skeletonema costatum (Grev.) Cleve, Ph.D. Dissertation, $125 \mathrm{pp}$. University of Washington, Seattle 1974

Davis, C.0.: Effects of changes in light intensity and photoperiod in the silicate-limited continuous culture of the marine diatom skeletonema costatum (Grev.) Cleve, Ph.D. Dissertation, $122 \mathrm{pp}$. University of Washington, Seattle 1973

-, P.J. Harrison and R.C. Dugdale: Continuous culture of marine diatoms under silicate limitation. I. Synchronized life cycle of Skeletonema costatum. J. Phycol. 9, 175-180 (1973)

Droop, M.R.: Some thoughts on nutrient limitation in algae. J. Phycol. 9, 264-272 (1973)

Eppley, R.W. and E.H. Renger: Nitrogen assimilation of an oceanic diatom in nitrogen-limited continuous cuiture. J. Phycol. 10, 15-23 (1974)

-, J.N. Rogers and J.I. McCarthy: Half-saturation constants for uptake of nitrate and ammonium by marine phytoplankton. Limnol. Oceanogr. 14, 912-920 (1969)

- and W.H. Thomas: Comparison of half-saturation constants for growth and nitrate uptake of marine phytoplankton. J. Phycol. 5, 375379 (1969)

Fisher, S., L. Buxbaum, K. Lath, E. Eisenstadt and $S$. Silver: Regulation of manganese accumulation and exchange in Bacillus subtilis W23. J. Bact. 113, 1373-1380 (1973)

Guillard, R.R.L. and J.H. Ryther: Studies of marine plankton diatoms. I. Cyclotella nana (Hustedt) and Detonula confervacea (Cleve) Gran. Can. J. Microbiol. 8, 229-239 (1962)

Harrison, P.J.: Continuous culture of the marine diatom Skeletonema costatum (Grev.) Cleve, under silicate limitation, Ph.D. Dissertation, $140 \mathrm{pp}$. University of Washington, Seattle 1974
-, H.L. Conway and R.C. Dugdale: Marine diatoms grown in chemostats under silicate or ammonium limitation. I. Cellular chemical composition and steady-state growth kinetics of skeletonema costatum. Mar. Biol. 35, 177-186 (1976)

Herbert, D., R. Elsworth and R.E. Telling: The continuous culture of bacteria: a theoretical and experimental study. J. gen. Microbiol. 14, $601-622$ (1956)

MacIsaac, J.J. and R.C. Dugdale: Interactions of light and inorganic nitrogen in controlling nitrogen uptake in the sea. Deep-Sea Res. $19,209-232(1972)$

North, B.B. and G.C. Stephens: Uptake and assimilation of amino acids by Platymonas. II. Increased uptake in nitrogen deficient cells. Biol. Bull. mar. biol. Lab., Woods-Hole 140 , 242-254 (1971)

Paasche, E.: Silicon and the ecology of marine plankton diatoms. II. Silicate-laptake kinetics in five diatom species. Mar. Biol. 19, 262-269 (1973)

Pavlou, S.P., G. Friederich and J.J. MacIsaac: Quantitative determination of total organic nitrogen and isotope enrichment in marine phytoplankton. Analyt. Biochem. 61, 16-24 (1974)

Rhee, G-Y.: A continuous culture study of phosphate uptake, growth rate and polyphosphate in Scenedesmus sp. J. Phycol. 9, 495-506 (1973)

Schaechter, M.: Growth: cells and populations. In: Biochemistry of bacterial cell growth, pp 136-162. Ed. by J. Mandelstom and $\mathrm{K}$. Mcquillen. New York: Wiley Press 1968

Shields, D.B. and J.E. Pollack: Chemostat Iaboratory operating system. Decoscope $12,1-2$ (1972)

Sims, A.P., B.F. Folkes and A.H. Bussey (in part): Mechanisms involved in the regulation of nitrogen assimilation in microoxganisms and plants. In: Recent aspects of nitrogen metabolism in plants, pp 91-114. Ed. by E.J. Hewitt and C.V. Cutting. New York, Academic Press 1968

Werner, D.: Die Kieselsäure im Stoffwechsel von Cyclotella cryptica Reiman, Lewis and Guillard. Arch. Mikrobiol. 55, 278-308 (1966)

Dr. H. Lee Conway

Radiological and Environmental Research Division Argonne National Laboratory Argonne, Illinois 60439 USA

Date of final manuscript acceptance: December 15, 1975. Communicated by M.R. Tripp, Newark 